to gather the necessary information and facts for themselves, Essential News, which is a weekly non. party bulletin, should serve a useful purpose. It is composed of quotations from various papers or periodicals and summaries of significant facts, together with constructive suggestions drawn from English and foreign sources. Thus, in a recent number special attention is devoted to economic reconstruction in Europe. There is a description of Delaisi's Five Year Plan for Europe, which advocates the planning of large schemes of work to reduce unemployment in Europe. The plan envisages the construction of great roads running north and south connecting the Baltic, Poland, the Danubian countries and the Mediterranean. This would open up an immense area in which some sixty million peasants are still living a primitive economic life. Another article in the same issue also bears on the construction of international roads; this is an extract from a pamphlet by Mr. J. E. Meade entitled "Public Works in their International Aspect". According to Mr. Meade, roads are cheaper to build than railways. The nineteenth century provided capital for railways; could not, he asks, the twentieth provide it for special motor roads? A European network of roads, roughly $\mathbf{9 , 0 0 0}$ miles in extent, financed by a European petrol tax of approximately one penny per gallon, built over a period of five years, would provide work for 188,000 workers in the first year, rising to three quarters of a million in the fifth year. The cost would be about 170 million pounds (gold). Some such roads already exist, in particular between Cologne and Bonn, between Milan and Turin, Como and Brescia, and one is being built between Rome and Naples.

\section{George Edwards's Picture of the Dodo}

THe biographical notice of George Edwards, the eighteenth century naturalist, which appeared in the January issue of Science Progress, may be amplified by some points of interest in regard to Edwards's picture of the dodo (Didus ineptus). Edwards, himself, tells us in the "Gleanings of Natural History", Part 2, 1760, that the coloured figure of the bird (Plate 294), was copied in 1757, as reduced, from a picture in oil-colours, of its natural size, this about thirty inches high. Further, that the original was drawn in Holland from the living bird from St. Maurice's Island (Mauritius) in the East Indies; that it was theproperty of $\mathrm{Sir}$ Hans Sloane, at the time of his death, becoming afterwards Edwards's property. The owner deposited (1759) the picture in the British Museum "as a great curiosity", and with Sloane's record. The original canvas, it may be mentioned, portrayed various other birds; also a few lizards and a toad. Edwards, however, simply selected the dodo for his plate, adding a guinea-pig for the sake of relative magnitude. It appears that the picture was copied in brighter colours (it was blackened through age) about 1877 by Mrs. I. Gunther, mother of Dr. Albert Gunther, keeper of the Zoological Department of the British Museum. From this copy, which is at Oxford, a postcard in colour was ultimately made, and is obtainable at the Old Ashmolean, Oxford. The large picture which hangs in the Bird Gallery of the Natural History Museum, South Kensington, is the original canvas, which has been cleaned; the postcards in colour available at the Museum are reproductions of this picture.

\section{Physical Bibliographies}

THe recent issue of the index numbers of the physics and the electrical engineering volumes of Science Abstracts completes these volumes for the year 1932. The physies volume deals with 5,364 abstracts in 1,316 pages and the electrical engineering one with 2,926 in 756 pages. While the latter is slightly larger than the 1931 volume and author and subject indexes are on the same lines as in previous years, the former is about twenty per cent larger and its subject index has been greatly improved and its length increased about twenty-eight per cent to 197 pages. Physics papers are divided into eight main classes, each class into sections, with keyheadings, and each section into sub-groups with subheadings. Forexample, a mainclass - general physicshas twenty-one key-headings, one of which is elasticity and plasticity. This has ten sub-headings, two of which are photoelasticity and vibrations, with cross references to acoustics, piezoelectricity, seismology and thermodynamics. The key-headings are arranged in alphabetical order throughout the index. These improvements will be welcomed by users of the volume. The Revue Bibliographique of the Journal de Physique for 1932 is not yet completed but the volume for 1931 devoted approximately 130 pages to the subject index, 160 to author index and 850 to abstracts. In the subject index the whole of the sections under a class appear together and are divided into sub-sections or groups.

\section{Veterinary Publications}

WrтH the January number (vol. 3, No. 1) the Veterinary Bulletin enters upon the third annual volume. A regular monthly issue, begun with vol. 2, will be continued, and by some adjustment of the lay-out of the pages more space will be available for a larger number of abstracts. In this first number, a list is given of the publications from which abstracts will be selected. The Veterinary Bulletin is published by the Imperial Bureau of Animal Health, Veterinary Laboratory, Ministry of Agriculture and Fisheries, Weybridge, Surrey, the annual subscription being $£ 2$. The Imperial Bureau of Animal Heaith also proposes to issue, should adequate support be forthcoming, under the title Index Veterinarius, a complete index to publications relating to veterinary research, administration, etc. An annual volume in crown quarto size would run to about 1,600 pages and a number, consisting of about 400 pages, would be issued each quarter. The Index would be prepared on a Gestetner duplicator: the sheets printed on orie side only, elear to read, and adequately glued, stitched, and bound. About 10,000 references would be indexed each year, with cross-indexing. The price would be $\mathfrak{f} 4$ the annual volume, including postage. 